OPEN ACCESS

Edited by:

Liana Fattore,

National Research Council (CNR), Italy

Reviewed by:

Marilyn A. Huestis,

Thomas Jefferson University,

United States

Dennis Sholler,

Johns Hopkins Medicine,

United States

*Correspondence:

Janni Leung

j.leung1@uq.edu.au

Specialty section:

This article was submitted to

Addictive Disorders,

a section of the journal

Frontiers in Psychiatry

Received: 18 November 2020 Accepted: 01 February 2021

Published: 18 February 2021

Citation:

Leung J, Stjepanović D, Dawson D and Hall WD (2021) Do Cannabis Users Reduce Their THC Dosages

When Using More Potent Cannabis

Products? A Review.

Front. Psychiatry 12:630602.

doi: 10.3389/fpsyt.2021.630602

\section{Do Cannabis Users Reduce Their THC Dosages When Using More Potent Cannabis Products? A Review}

\author{
Janni Leung ${ }^{1,2 *}$, Daniel Stjepanović ${ }^{1}$, Danielle Dawson ${ }^{1,2}$ and Wayne D. Hall ${ }^{1}$ \\ ${ }^{1}$ National Centre for Youth Substance Use Research, The University of Queensland, St Lucia, QLD, Australia, ${ }^{2}$ School of \\ Psychology, The University of Queensland, St Lucia, QLD, Australia
}

Background: Higher potency cannabis products are associated with higher risks of negative physical and psychological outcomes. The US cannabis industry has opposed any restrictions on THC levels, arguing that people titrate their THC doses when consuming higher potency products.

Objective: To review research on the degree to which people who use cannabis for recreational purposes can and do titrate their THC doses.

Method: A systematic search was conducted for studies published from 1973 to 2020. We included (1) experimental laboratory studies on dose titration of cannabis products that varied in THC content; (2) observational studies on the use of more potent products; and (3) surveys on whether cannabis users titrate when using more potent products.

Results: In some experiments, there were inverse associations between the THC content and the amount smoked and smoking topography, while others indicated higher doses consumed and psychological and physiological effects observed. Findings of observational studies of regular cannabis users were more equivocal. In some surveys, cannabis users reported that they use less when using more potent products, but in other surveys, persons who used more potent cannabis had more adverse effects of use.

Discussion: There is some evidence from experimental studies that people who use higher potency cannabis for recreational purposes can titrate their THC doses, but less evidence that regular cannabis users do in fact do so. We need much better experimental and epidemiological research to inform the design of regulatory policies to minimize harms from the use of high THC cannabis products.

Keywords: cannabis, marijuana, titration, THC concentration, dose

\section{INTRODUCTION}

In some states in the USA, the legalization of cannabis for adult and medical use has increased the availability and sales of cannabis products, such as extracts, that have a THC content $>70 \%$ (1). The cannabis industry has resisted proposals to cap THC content by arguing that people who use high potency cannabis extracts titrate their doses (e.g., reduce their THC dosage of higher potency cannabis products to achieve the same desired psychoactive effects). They may, for example, reduce 
the amount smoked when using high THC products. They may also inhale smaller puffs or do so less often when using higher potency products (2). The ability to do so will depend upon users understanding the relationship between product potency and their desired effects so that they can titrate their THC dose (3).

We systematically reviewed evidence on the degree to which people who use cannabis for recreational purposes can and do reduce their THC dose when using more potent products.

\section{METHODS}

\section{Eligibility Criteria}

We included original studies published from 1973 to the date of our search (17 June 2020) if they reported quantitative data on behavior indicative of titrating THC doses from cannabis products (via any route of administration) that varied in THC content (e.g., by varying or controlling the amount rolled, inhaled, or consumed).

We excluded studies of medicinal cannabis use and clinical/pharmacological studies where patients/participants were instructed to titrate their dose of cannabis consumption. Our review aimed to examine evidence on recreational cannabis use in non-supervised settings to better inform public health policy on the regulation of recreational cannabis use.

\section{Search Strategy}

The search was conducted in PubMed and Embase with terms related to "Cannabis" AND 'Titration' in the title/abstract/related $\mathrm{MeSH}$ and Emtree explosion subject headings, with the "Humans" filter applied, as follows:

PubMed search: ((cannabis [tiab] OR marijuana [tiab] OR Cannabis [MeSH] OR Marijuana Use [MeSH] OR Marijuana Smoking* [MeSH])) AND ((titration [tiab] OR self-titration [tiab] OR self-titrating [tiab] OR self-titra* [tiab] OR titrant [tiab] OR titrat* [tiab] OR auto-titration [tiab] OR autotitration [tiab])) AND (humans[Filter]).

Embase search: (((cannabis:ti,ab OR marijuana:ti,ab OR “cannabis"/exp OR "marijuana use"/exp OR “marijuana smoking*”) AND (titration:ti,ab OR “self-titration":ti,ab OR "self-titrating":ti,ab OR "self titra*":ti,ab OR titrant:ti,ab OR titrat*:ti,ab OR “auto titration":ti,ab OR autotitration:ti,ab)) AND "human"/de) AND ("article"/it OR "article in press"/it OR “review”/it).

The supplementary search involved the authors' collection and a snowball search of secondary references identified from all relevant records from the database search and authors' collection. Two researchers carried out the screening, study selection, and data extraction.

\section{Synthesis of Results}

Findings from experimental and observational studies and surveys were synthesized narratively on evidence of: (1) titration behavior (e.g., amount smoked, smoking topography) and (2) evidence of effective titration, defined as adjusting consumption when using high THC products to deliver the same THC dose or to achieve the same physiological, neurobehavioral, or psychological effects obtained from using a lower dose product.

\section{RESULTS}

\section{Study Characteristics}

We identified 197 records from the database search and 338 records from the supplementary search, from which, we screened 497 unique titles after exclusion of duplicates. After full-text screening $(n=81)$, we included 15 articles (Supplementary Figure 1).

Most studies were from the USA $(n=9)$, with smaller numbers from the UK $(n=1)(4)$, Canada $(n=2)(5,6)$, and the Netherlands $(n=3)(2,7,8)$. Five studies were published after $2010(2,4,9-11)$.

Experimental laboratory studies (Table 1a) recruited young volunteers who were experienced cannabis users and asked them to smoke cannabis that varied in THC concentration (e.g., (9, 10)). Observational studies (Table 1b) examined the cannabis use behavior of users $(2,4)$. Surveys of cannabis users (Table 1c) asked users whether they varied their patterns of use when using more potent cannabis products/assessed whether their reports of adverse effects of cannabis varied with the potency of the cannabis products that they used.

\section{Narrative Review Experimental Laboratory Studies}

There was mixed evidence of titration in experimental studies that were conducted in the 70-90's $(5,6,12-17)$. These studies used various methods to measure dose titration (e.g., measuring the total amount of THC that was self-administered and assessing the physiological, and psychological effects of the cannabis consumed).

Some of these studies reported differences in smoking topography, such as taking smaller puffs, smaller inhalation volumes, shorter puff duration, longer inter-puff intervals, when using more potent cannabis products $(6,13,16)$. Other studies did not $(5,12,15)$. The participants in the higher dose conditions in all studies consumed more THC and reported more psychoactive effects, regardless of adjustments in their smoking behavior.

More recent studies have found some evidence of titration. Hartman et al. conducted an experimental study that evaluated the cannabinoid levels in blood and plasma after the use of vaporized cannabis that varied THC content, with and without alcohol consumption, while allowing ad-libitum consumption $(9,10)$. They recruited 32 participants who had used cannabis in the past 3 months no more than three times a week. Nineteen (59\%) completed all the sessions and provided data on cannabinoid levels in blood and plasma concentrations (10) and oral fluid (9). Participants inhaled vaporized cannabis (ground cannabis obtained through NIDA) ad-libitum for $10 \mathrm{~min}$. The THC levels were $0.008 \%$ in the placebo, $2.9 \%$ in the low and $6.7 \%$ in the high concentration cannabis conditions. Participants consumed the three cannabis products with and without a concurrent low-dose alcoholic beverage, across six testing sessions. 
TABLE 1 | Summary of experimental (a), observational (b), and survey (c) studies on titration of recreational cannabis products by potency.

\begin{tabular}{|c|c|c|c|c|c|c|c|}
\hline $\begin{array}{l}\text { First author (year } \\
\text { published), study } \\
\text { location }\end{array}$ & $\begin{array}{l}\text { Study design } \\
\text { (sample size) }\end{array}$ & $\begin{array}{l}\text { Sample } \\
\text { characteristics }\end{array}$ & $\begin{array}{l}\text { Cannabis } \\
\text { products } \\
\text { examined }\end{array}$ & Titration measure & Summary of findings & $\begin{array}{l}\text { Evidence of } \\
\text { titration } \\
\text { behavior }\end{array}$ & $\begin{array}{l}\text { Evidence of } \\
\text { effective } \\
\text { titration }^{\dagger}\end{array}$ \\
\hline
\end{tabular}

\section{(a) Summary of experimental studies on titration of recreational cannabis products by potency}

$\begin{array}{llll}\text { Cappell et al. (5), } & \text { Experimental, in } & \text { Experienced in } & 0.8 \text { vs. } 0.4 \% \text { or } \\ \text { Canada } & \text { lab, }(\mathrm{N}=12) & \text { cannabis use, } & 0.2 \% \text { THC flower } \\ & & \text { aged } 21-28, & \text { (as cigarettes) }\end{array}$

Total time with smoke in lungs,

number of puffs, mean duration of

Effective titration of intake did not

ged $21-28$

puff, mean interval between puffs,

estimated weight of material

consumed, finger pulse, blood

pressure, and conjunctival injection.

Number of puffs and duration

for which puffs were held in lungs did

not differ as a function of THC

concentration.

The greater the potency of the

products, the more total THC

participants consumed.

Cappell and Pliner

Experimental, in

Frequent or

Behavioral tasks: pursuit rotor, verbal memory, and raw reaction time.

(6), Canada lab, $(N=60)$

infrequent

1.45 vs. $0.73 \%$ or

Cigarette size (small and large), pulse

cannabis use,

$0.36 \%$ THC flower

rate, number/duration/intervals

aged 18-29 (mean

(as cigarette)

between inhalations.

There was some evidence of titration behavior with the amount of cannabis

Experienced in cannabis use, aged 21-33,

2.9 vs. $0.5 \%$ (as males

cigarette)

Amount of cigarettes smoked/THC concentration; effects on size of palpebral fissure and pupil diameter; patellar reflex and heart rate; mood as assessed by Clyde Mood test scores.

Perez-Reyes et al. Experimental, in Experienced in $\quad 2.54$ vs. 1.32 vs. cannabis use, aged 23-36, 50\% $2.54 \mathrm{vs.}$
$1.97 \%$

Smoking time, number of puffs, length of puff, length of hold, interval between puffs, THC plasma concentration, peak subjective high, cardiac acceleration via electrocardiogram (ECG).

consumed increasing as potency decreased.

Participants in the more potent conditions, however,

self-administered more total THC, attaining the same subjective endpoint of intoxication.

After being asked to smoke as much as they could, participants in the higher concentrate condition had a

higher increase in the amplitude of the patellar reflex and heart rate, blood pressure, pulse rate changes, and on self-reported mood.

THC cigarette consumption was

dose-dependent when comparing

high to low THC content, but there was no evidence of effective titration in THC plasma levels, heart rate acceleration, or reported subjective high. 
TABLE 1 | Continued

\begin{tabular}{|c|c|c|c|c|c|c|c|}
\hline $\begin{array}{l}\text { First author (year } \\
\text { published), study } \\
\text { location }\end{array}$ & $\begin{array}{l}\text { Study design } \\
\text { (sample size) }\end{array}$ & $\begin{array}{l}\text { Sample } \\
\text { characteristics }\end{array}$ & $\begin{array}{l}\text { Cannabis } \\
\text { products } \\
\text { examined }\end{array}$ & Titration measure & Summary of findings & $\begin{array}{l}\text { Evidence of } \\
\text { titration } \\
\text { behavior }\end{array}$ & $\begin{array}{l}\text { Evidence of } \\
\text { effective } \\
\text { titration }^{\dagger}\end{array}$ \\
\hline $\begin{array}{l}\text { Herning et al. (14), } \\
\text { USA }\end{array}$ & $\begin{array}{l}\text { Experimental, in } \\
\text { lab, }(N=10)\end{array}$ & $\begin{array}{l}\text { Experienced in } \\
\text { cannabis use, } \\
\text { mean age }=29, \\
\text { males }\end{array}$ & $\begin{array}{l}3.9 \text { vs. } 1.2 \% \text { (as } \\
\text { cigarette) }\end{array}$ & $\begin{array}{l}\text { Number of puffs, inter-puff interval, } \\
\text { puff volume, puff duration, inhalation } \\
\text { volume, inhalation duration, } \\
\text { cumulative puff volume, cumulative } \\
\text { inhalation volume, total smoking } \\
\text { duration; physiological measures: } \\
\text { heart rate, blood pressure, skin } \\
\text { temperature, and expired CO; verbal } \\
\text { self-report of subjective high. }\end{array}$ & $\begin{array}{l}\text { The high potency cigarettes were } \\
\text { smoked with more puffs and longer } \\
\text { inter-puff intervals with greater inhaled } \\
\text { volumes of air, thereby diluting the } \\
\text { cannabis smoke. } \\
\text { Skin temperature and intoxication } \\
\text { rating significantly differed between } \\
\text { low and high potency conditions. }\end{array}$ & Yes & No \\
\hline Chait (15), USA & $\begin{array}{l}\text { Experimental, in } \\
\text { lab, }(N=10)\end{array}$ & $\begin{array}{l}\text { Experienced in } \\
\text { cannabis use, } \\
\text { aged } 19-33 \text { (mean } \\
=23 \text { ), } 80 \% \text { males }\end{array}$ & $\begin{array}{l}0.9 \text { vs. } 1.7 \text { vs. } \\
2.7 \% \text { THC (as } \\
\text { cigarette) }\end{array}$ & $\begin{array}{l}\text { Amount of cigarettes smoked, cut-off } \\
\text { time, expired carbon monoxide levels, } \\
\text { heart rate, cigarette questionnaire } \\
\text { (taste, harshness, draw), visual analog } \\
\text { scales, Addiction Research Center } \\
\text { Inventory (ARCI), mood via Profile of } \\
\text { Mood States (POMS) questionnaire. }\end{array}$ & $\begin{array}{l}\text { The post-smoking increase in expired } \\
\text { air carbon monoxide levels and } \\
\text { psychological measures did not differ } \\
\text { between the conditions. }\end{array}$ & No & No \\
\hline $\begin{array}{l}\text { Heishman et al. } \\
\text { (16), USA }\end{array}$ & $\begin{array}{l}\text { Experimental, in } \\
\text { lab, }(N=12)\end{array}$ & $\begin{array}{l}\text { Experienced in } \\
\text { cannabis use, } \\
\text { aged 23-43 (mean } \\
\text { age }=31 \text { ), males }\end{array}$ & 2.7 vs. 1.3 vs. $0 \%$ & $\begin{array}{l}\text { Heart rate, smoking topography } \\
\text { (inter-puff interval, puff duration, puff } \\
\text { volume, maximum flow rate/puff, } \\
\text { average flow rate/puff); subjective } \\
\text { report of drug effects; a cognitive } \\
\text { battery measuring working memory, } \\
\text { attention, and motor ability } \\
\text { (digit-symbol substation task). }\end{array}$ & $\begin{array}{l}\text { Participants in the high dose } \\
\text { condition took smaller puffs, lesser } \\
\text { inhalation volumes and shorter puff } \\
\text { duration, but did not differ in other } \\
\text { smoking topography measures. } \\
\text { There was no effect on } \\
\text { attention-digit span/symbol } \\
\text { substation tasks results did not show } \\
\text { a dose-response effect. However, } \\
\text { subjective reports of dose-related } \\
\text { effects of cannabis were obtained. }\end{array}$ & Yes & No \\
\hline $\begin{array}{l}\text { Matthias et al. (17), } \\
\text { USA }\end{array}$ & $\begin{array}{l}\text { Quasi- } \\
\text { experimental, in } \\
\text { lab, }(N=10)\end{array}$ & $\begin{array}{l}\text { Experienced in } \\
\text { cannabis use, } \\
\text { mean age }=23 \text {, } \\
\text { males }\end{array}$ & $\begin{array}{l}3.95 \text { vs. } 1.77 \text { vs. } \\
0 \%\end{array}$ & $\begin{array}{l}\mathrm{COHb} \text { saturation, self-report } \\
\text { subjective level of intoxication, volume } \\
\text { and number of puffs and inter-puff } \\
\text { intervals, inhaled volume, } \\
\text { breath-holding time, respiratory THC } \\
\text { retention, heart rate. }\end{array}$ & $\begin{array}{l}\text { Participants in the stronger dose } \\
\text { condition showed reduced intake of } \\
\text { smoke and tar yield. } \\
\text { THC retention and heart rate were } \\
\text { increased in the higher THC } \\
\text { concentrations. }\end{array}$ & Yes & No \\
\hline
\end{tabular}




\begin{tabular}{|c|c|c|c|c|c|c|c|}
\hline $\begin{array}{l}\text { First author (year } \\
\text { published), study } \\
\text { location }\end{array}$ & $\begin{array}{l}\text { Study design } \\
\text { (sample size) }\end{array}$ & $\begin{array}{l}\text { Sample } \\
\text { characteristics }\end{array}$ & $\begin{array}{l}\text { Cannabis } \\
\text { products } \\
\text { examined }\end{array}$ & Titration measure & Summary of findings & $\begin{array}{l}\text { Evidence of } \\
\text { titration } \\
\text { behavior }\end{array}$ & $\begin{array}{l}\text { Evidence of } \\
\text { effective } \\
\text { titration }^{\dagger}\end{array}$ \\
\hline \multirow[t]{2}{*}{$\begin{array}{l}\text { Hartman et al. } \\
(10), \text { USA }\end{array}$} & $\begin{array}{l}\text { Experimental, in } \\
\text { lab, }(N=19)\end{array}$ & $\begin{array}{l}\text { Used in past } 3 \\
\text { months, at most } \\
\text { three times/ week, } \\
\text { aged 21-37, 72\% } \\
\text { males }\end{array}$ & $\begin{array}{l}\text { Placebo (0.008\%), } \\
\text { low (2.9\%), vs. } \\
\text { high }(6.7 \%) \text { THC; } \\
\text { ground bulk } \\
\text { cannabis } \\
\text { vaporized } \\
\text { ad-libitum for } \\
10 \text { min }\end{array}$ & $\begin{array}{l}\text { Blood and plasma cannabinoid } \\
\text { analysis. }\end{array}$ & $\begin{array}{l}\text { Of participants that completed all } \\
\text { experimental sessions, } 10 \text { showed } \\
\text { self-titration as indexed by maximum } \\
\text { blood THC concentration ( } \mu \mathrm{g} / \mathrm{L}) \text {. }\end{array}$ & - & Mixed \\
\hline & & & & $\begin{array}{l}\text { No behavioral measures of titration } \\
\text { presented. }\end{array}$ & $\begin{array}{l}\text { Low concentration cannabis sessions } \\
\text { produced consistent max } \\
\text { concentration and AUC values in } \\
\text { participants, whereas high dose } \\
\text { products did not. }\end{array}$ & & \\
\hline \multirow[t]{2}{*}{$\begin{array}{l}\text { Hartman et al. (9), } \\
\text { USA, }\end{array}$} & $\begin{array}{l}\text { Experimental, in } \\
\text { lab, }(N=19)\end{array}$ & $\begin{array}{l}\text { Used in past } 3 \\
\text { months, at most } \\
\text { three times/ week, } \\
\text { aged } 21-37,72 \% \\
\text { males }\end{array}$ & $\begin{array}{l}\text { Placebo }(0.008 \%) \text {, } \\
\text { low }(2.9 \%) \text {, or high } \\
(6.7 \%) \text { THC; } \\
\text { ground bulk } \\
\text { cannabis } \\
\text { vaporized vs. } \\
\text { libitum for } 10 \mathrm{~min}\end{array}$ & Oral fluid THC concentration. & $\begin{array}{l}\text { Max THC concentrations in oral fluid } \\
\text { were higher in active (low and high) } \\
\text { dose cannabis conditions than } \\
\text { placebo. No difference in oral fluid } \\
\text { THC were detectable between low } \\
\text { and high dose overall or at any } \\
\text { timepoint post-dose. Given that } \\
\text { differences in blood and plasma were } \\
\text { detected in some participants, this } \\
\text { suggests a failure of oral fluid THC } \\
\text { sensitivity. }\end{array}$ & - & Mixed \\
\hline & & & & $\begin{array}{l}\text { Blood and plasma cannabinoid (also } \\
\text { reported in Hartman et al. (10)). }\end{array}$ & & & \\
\hline $\begin{array}{l}\text { Bidwell et al. (11), } \\
\text { USA }\end{array}$ & $\begin{array}{l}\text { Experimental } \\
\text { (between- } \\
\text { subjects), sample } \\
\text { recruited via social } \\
\text { media and mailed } \\
\text { flier adverts, ( } N= \\
\text { 121) }\end{array}$ & $\begin{array}{l}\text { Experienced } \\
\text { flower or } \\
\text { concentrate use, } \\
\text { mean age = 28, } \\
55-64 \% \text { males }\end{array}$ & $\begin{array}{l}\text { Concentrates ( } 70 \\
\text { vs. } 90 \%) \text { or flowers } \\
\text { (16 vs. } 24 \%)\end{array}$ & $\begin{array}{l}\text { Plasma cannabinoids; subjective drug } \\
\text { intoxication; mood via modified } \\
\text { POMS questionnaire; neurobehavioral } \\
\text { tasks testing memory, inhibitory } \\
\text { control, eyes open, and closed } \\
\text { balance. }\end{array}$ & $\begin{array}{l}\text { THC exposure was significantly } \\
\text { higher in the concentrates conditions. } \\
\text { Neuro-behavioral outcomes did not } \\
\text { differ by potency. }\end{array}$ & - & Mixed \\
\hline \multicolumn{8}{|c|}{ (b) Summary of naturalistic observational studies on titration of recreational cannabis products by potency } \\
\hline $\begin{array}{l}\text { Freeman et al. (4), } \\
\text { United Kingdom }\end{array}$ & $\begin{array}{l}\text { Naturalistic } \\
\text { observational, } \\
\text { recruited by } \\
\text { word-of-mouth } \\
\text { and snowball } \\
\text { sample, }(N=247)\end{array}$ & $\begin{array}{l}\text { Used daily, mean } \\
\text { age }=20,74 \% \\
\text { males }\end{array}$ & $\begin{array}{l}\text { Own cannabis } \\
\text { products varying in } \\
\text { potency (1-10) } \\
\text { and type (skunk, } \\
\text { resin, or herbal); } \\
\text { samples analyzed } \\
\text { for THC } \\
\text { concentrations }\end{array}$ & $\begin{array}{l}\text { Consumption behavior observed from } \\
\text { participants smoking their own } \\
\text { cannabis in front of the researcher. } \\
\text { Self-reported subjective intoxication. } \\
\text { Verbal IQ assessed using Wechsler } \\
\text { Test of Adult Reading (WTAR). }\end{array}$ & $\begin{array}{l}\text { There was a negative association } \\
\text { between THC concentration and } \\
\text { amount of cannabis used, but } \\
\text { non-daily users were poor in potency } \\
\text { estimation. }\end{array}$ & Yes & Incomplete \\
\hline
\end{tabular}




\begin{tabular}{|c|c|c|c|c|c|c|c|}
\hline $\begin{array}{l}\text { First author (year } \\
\text { published), study } \\
\text { location }\end{array}$ & $\begin{array}{l}\text { Study design } \\
\text { (sample size) }\end{array}$ & $\begin{array}{l}\text { Sample } \\
\text { characteristics }\end{array}$ & $\begin{array}{l}\text { Cannabis } \\
\text { products } \\
\text { examined }\end{array}$ & Titration measure & Summary of findings & $\begin{array}{l}\text { Evidence of } \\
\text { titration } \\
\text { behavior }\end{array}$ & $\begin{array}{l}\text { Evidence of } \\
\text { effective } \\
\text { titration }^{\dagger}\end{array}$ \\
\hline & & & & & $\begin{array}{l}\text { Cannabis product type influenced } \\
\text { THC and CBD concentrations. } \\
\text { User-estimated potency, in turn, } \\
\text { differed as a function of product type, } \\
\text { and therefore potency. Amount of } \\
\text { product consumed was not } \\
\text { influenced by product type/potency. } \\
\text { Subjective intoxication did not differ. }\end{array}$ & & \\
\hline $\begin{array}{l}\text { van der Pol et al. } \\
\text { (2), Netherlands }\end{array}$ & $\begin{array}{l}\text { Naturalistic } \\
\text { observational, } \\
\text { "coffee-shops" } \\
\text { and chain referral } \\
\text { sample, }(\mathrm{N}=98)\end{array}$ & $\begin{array}{l}\text { Experienced in } \\
\text { cannabis use, } \\
\text { aged } 19-32 \text { (mean } \\
=24), 75 \% \text { males }\end{array}$ & $\begin{array}{l}\text { Own products } \\
\text { varying in THC } \\
\text { concentration, and } \\
\text { comparisons of } \\
15.72 \text { vs. } 3.64 \%\end{array}$ & $\begin{array}{l}\text { Smoking topography measured using } \\
\text { a portable device [puff volume, } \\
\text { duration, inter-puff interval, average } \\
\text { velocity (ml/second), peak flow } \\
(\mathrm{ml} / \text { second), time to peak puff velocity } \\
(\mathrm{mll})]\end{array}$ & $\begin{array}{l}\text { Higher THC concentration was } \\
\text { associated with lower inhalation } \\
\text { volume and pace, but not with other } \\
\text { topography measures, and positively } \\
\text { associated with amount used. The } \\
\text { sub-group who used the highest THC } \\
\text { product (15.72\%) inhaled less than } \\
\text { users of average products ( } 3.64 \%), \\
\text { but the inhalation only halved when } \\
\text { the THC concentration was four times } \\
\text { higher. }\end{array}$ & Mixed & Incomplete \\
\hline \multicolumn{8}{|c|}{ (c) Summary of survyes of cannabis users on titration of recreational cannabis products by potency } \\
\hline $\begin{array}{l}\text { Reinarman (8), } \\
\text { USA \& } \\
\text { Netherlands }\end{array}$ & $\begin{array}{l}\text { Household survey, } \\
\text { (San Francisco } N \\
=266 ; \\
\text { Amsterdam } N= \\
216 \text { ) }\end{array}$ & $\begin{array}{l}\text { Experienced in } \\
\text { cannabis use, } \\
\text { mean age }= \\
\text { 34-37, 53-59\% } \\
\text { males }\end{array}$ & $\begin{array}{l}\text { "Stronger } \\
\text { cannabis" }\end{array}$ & $\begin{array}{l}\text { One self-report item: "When using } \\
\text { stronger cannabis, do you use..." } \\
\text { Less, Same, or More? }\end{array}$ & $\begin{array}{l}\text { Seventy percent of participants } \\
\text { self-reported that they use less when } \\
\text { using stronger cannabis }\end{array}$ & Yes & - \\
\hline $\begin{array}{l}\text { Korf et al. (7), } \\
\text { Netherlands }\end{array}$ & $\begin{array}{l}\text { "Coffee-shops" } \\
\text { field interviews, (N } \\
=388)\end{array}$ & $\begin{array}{l}\text { Smoked cannabis } \\
\text { in last } 30 \text { days, } \\
\text { mean age }=28 \\
79 \% \text { males }\end{array}$ & $\begin{array}{l}\text { Own products } \\
\text { with dosage } \\
\text { assessed using a } \\
\text { prompt card } \\
\text { showing } 0.05 \text {, } \\
0.10,0.20,0.30 \mathrm{~g} \\
\text { of cannabis/hash }\end{array}$ & $\begin{array}{l}\text { Self-report of (a) consumption } \\
\text { characteristics measured using } \\
\text { validated tools, and (b) } \\
\text { self-adjustment behaviors in the } \\
\text { hypothetical situations that they were } \\
\text { smoking more potent products. }\end{array}$ & $\begin{array}{l}\text { Three broad types of cannabis users } \\
\text { were identified with mixed results. The } \\
\text { type who preferred milder cannabis } \\
\text { reported compensating by inhaling } \\
\text { less deeply and smoking less. } \\
\text { However, the youngest group who } \\
\text { consumed the highest monthly dose } \\
\text { reported inhaling more deeply, and } \\
\text { the oldest group did not report } \\
\text { adjustments to intake. }\end{array}$ & Mixed & - \\
\hline
\end{tabular}

-, not reported; -, not assessed; AUC, area under the concentration-time curve; CBD, cannabidiol; CO, carbon monoxide; COHb, Carboxyhemoglobin, carbon monoxide that formed when inhaled; THC, tetrahydrocannabinol; POMS, Profile of Mood States.

†Effective titration was defined as adjustments in consumption behavior when using high THC products that resulted in no increase in THC exposure or no differences in neurobehavioral effects. 
In the analyses of blood and plasma THC concentrations (10) 10 of the 19 participants showed evidence of dose titration as indexed by maximum blood THC concentration $(\mu \mathrm{g} / \mathrm{L})$. Specifically, four participants had THC concentrations for the low and high concentration conditions were within $20 \%$ of each other, and six participants had greater THC concentrations in the low than the high cannabis condition. Sessions using low concentration cannabis produced consistent THC blood max concentration and AUC values whereas higher dose products did not. This suggests that users attempted to titrate their dose. Data were not presented separately for alcohol and no alcohol conditions, but there were no significant interactions between cannabis dose and alcohol consumption in their effects on THC concentration or AUC.

Bidwell et al. (11) reported a between-subjects experimental study in cannabis users who predominantly used flower/concentrates. They measured blood levels of cannabinoids and the active THC metabolite 11-hydroxy $\Delta^{9}$ THC (11-OH-THC) and assessed subjective intoxication and mood, and performance on memory, inhibitory control, and balance. Participants were randomly assigned to smoke cannabis products of their preferred type that were standardized to contain either low (flower: 16\%; concentrate: 70\%) or high (flower $24 \%$, concentrate $90 \%$ ) THC concentrations.

Blood THC and THC metabolite levels differed between the two forms of cannabis, with concentrates producing higher blood levels than flower (11). There was no significant difference in levels between the two potency levels for cannabis concentrate (70 vs. $90 \%$ THC). For cannabis flower, the difference in blood levels approached the pre-specified significance threshold of $p<0.01$ for blood THC $(p=0.01)$ and 11-OH-THC $(p=0.02)$. Although this effect was not nominally significant, it suggested that participants who predominantly used flower experienced more difficulty adjusting their THC intake.

Concentrate users achieved more than double the mean blood THC level of flower users (11). Despite this difference, self-reported measures of intoxication did not differ between users of the two products. The reason for this discrepancy is unclear. Possible explanations include increased tolerance to THC in concentrate users, a saturation of the cannabinoid receptors so that additional THC intake no longer produced an effect, or differences in user characteristics that affect metabolism/sensitivity to THC. Potency did not significantly affect any of the neurobehavioral measures.

\section{Observational Studies}

Observational studies of cannabis users' behavior when using cannabis that varied in potency have shown mixed evidence of titration $(2,4)$.

Freeman et al. (4) reported an observational study in the UK in which participants used their own cannabis that chemical analyses had established varied in potency and type (skunk, resin, and herbal). Participants were asked to roll a joint and smoke it normally while the researcher recorded their self-reported subjective intoxication and assessed their verbal IQ using the Wechsler Test of Adult Reading.
The study found a negative relationship between THC concentration of the cannabis and the amount of cannabis added to their joints. This relationship was not influenced by the users' frequency of use. The THC levels of the cannabis products were positively correlated with participants' estimation of their potency but the correlation was low. The amount of cannabis consumed was not influenced by product type/potency and participants did not differ in their subjective levels of intoxication.

A similar study in the Netherlands by van der Pol et al. found mixed evidence on whether experienced cannabis users could successfully titrate their THC doses (2). This was a naturalistic, observational study of young experienced cannabis users recruited through "coffee-shops" and chain referrals. The participants used their own cannabis products that varied in THC concentration. Smoking topography was measured using a portable device to assess puff volume, duration, inter-puff interval, average velocity $(\mathrm{ml} / \mathrm{s})$, peak flow $(\mathrm{ml} / \mathrm{s})$, and time to peak puff velocity $(\mathrm{ml})$.

van der Pol et al. (2) found a positive association between cannabis THC concentration and the amount of cannabis consumed (i.e., participants who used more potent cannabis used larger amounts in their regular joints). There was, however, a negative association between THC concentration of joints and total inhaled smoke volume. This indicated that users inhaled less cannabis smoke when using cannabis with higher THC concentrations. Despite this, they consumed larger amounts when using high potency cannabis. This suggests that their attempt to titrate their doses was only partially successful as measured by THC in blood plasma.

\section{Surveys of Cannabis Users' Behavior}

A survey comparing patterns of cannabis use in San Francisco and Amsterdam is often cited as evidence for titration (8). In this study cannabis users were asked: "When using stronger cannabis, do you use less, same, or more?" Onethird of respondents reported that they used the same amount, and two-thirds reported that they used less. Those who reported smoking less of "stronger cannabis" said that they preferred to achieve the same effect by using less cannabis. This study can be considered as hypothesisgenerating, because it did not employ puff topography or measure THC.

Korf et al. (7) conducted a survey of Netherlands "coffeeshop" patrons who used cannabis and hash products that varied in potency. They collected data on self-reported behavior when smoking more potent cannabis products and identified three groups of users. The first group that varied in age and sex and preferred to use milder cannabis reported inhaling less deeply and smoking smaller amounts of higher potency cannabis. The second was a younger group with more symptoms of cannabis dependence who reported that they inhaled more potent products more deeply. The third comprised older predominantly males with long cannabis careers who lived and smoked alone. They did not report any adjustments in smoking behavior when they used more potent cannabis. 


\section{DISCUSSION}

This review found mixed evidence on how successful cannabis users were in adjusting their dose of more potent cannabis to achieve the same delivery of THC or the same desired psychoactive effects. Older experimental studies found little evidence for titration but often used cannabis with much lower THC levels that differed minimally between conditions. More recent experimental studies of ad-libitum cannabis provided some evidence of titration by finding reductions in the amount of THC in blood and plasma when products of different potency were used. An experimental study of controlled cannabis vaporization found similar THC concentrations in blood in the low and high dose THC conditions in some, but not all, participants. This provides some support that some cannabis users titrate their THC dose during ad-libitum consumption $(9,10)$.

Observational studies found weak evidence that cannabis smokers reduced their THC doses when using cannabis products with higher levels of THC. In surveys, there were self-reported changes in cannabis use but no assessments were made of whether these produced differences in the THC dose consumed or in its physiological or psychological effects.

The question of most relevance to cannabis policy is whether the users of higher THC products do, in fact, titrate their doses. Epidemiological surveys of adverse effects reported by cannabis users suggest that users of more potent cannabis products incompletely adjust their THC doses. In these surveys, consumers of higher THC cannabis products report more negative consequences than users of less potent products (18, 19). A UK cohort study showed that users of high potency cannabis had higher risks of generalized anxiety and cannabis use disorders (20).

There are supportive trends in ecological data. In the USA emergency, hospital, and poisoning center presentations related to cannabis have increased along with the increased use of high THC cannabis products after cannabis legalization (21). In the Netherlands, there was an increase in the number of persons seeking help to quit cannabis as the average THC content of cannabis sold in coffee shops increased and a later fall in numbers when THC content declined (3).

\section{Limitations of the Evidence}

This review was severely limited by the dearth of rigorous studies on whether people who use cannabis can effectively titrate their doses of higher potency cannabis. The recent rapid increase in THC potency in cannabis products on the market makes it difficult to compare the findings of early studies that used very low THC cannabis products by comparison with cannabis products now consumed.

There may also have been changes over time in the characteristics of people who use cannabis and in their frequency of use. Tolerance develops with the frequency of cannabis intake so cannabis effects will differ between the occasional users often studied in laboratories and the daily cannabis users who account for most of the cannabis consumed (22).
Routes of administration have also changed over time. Although we did not restrict our search to studies of any specific route of administrations, all the studies we included were of inhaled cannabis products. Methods and ease of titration between different routes of cannabis administration may vary. Vaporization and smoking provide similar cannabinoid delivery (23), but the subjective effects of edible products have a longer time course and users may be at risk of consuming more than intended if they had not waited for them to take effect before deciding to consume more. There are doubts about how well users can titrate their THC doses of oral cannabis products, given that individuals may not know how long they need to wait to assess whether they have reached their desired level of intoxication. Future studies are needed on self-titration of cannabis use by new and emerging administration methods.

Some early laboratory studies of cannabis consumption assessed the relationship between blood concentrations of THC and the effects of cannabis (24). However, many surveys have only assessed titration by self-report rather than measuring the THC content of cannabis or the level of users' intoxication. Self-reported titration can be subject to selective reporting, memory effects and bias and hence provides weak evidence for the titration.

Smoking topography was measured in some studies, with some authors arguing that it is difficult to assess titration without these measures (16). The use of behavioral endpoints as measures is problematic because frequent users have higher tolerance. Objective measures of cannabis potency and THC exposure, such as assessing THC concentration in blood and plasma in laboratory settings, are required in future research on cannabis dose titration.

This review was restricted to papers written in English. The predominance of studies from North America may limit the generalisability of these results. The marketing of high THC content products in the USA may have global impacts as online markets are increasingly popular and merchants accessible through online crypto-markets in the USA are prepared to ship cannabis products worldwide (25).

Our review excluded studies of cannabis when used to alleviate symptoms of chronic medical or mental health conditions. Future research is needed that monitors the prevalence of medical use and assesses the extent to which medicinal cannabis users titrate their doses.

There is an urgent need for larger and better controlled experimental and observational studies of the extent to which cannabis users can and do titrate their THC doses when using more potent cannabis products, such as, cannabis extracts and high potency cannabis flower. This research is needed to inform policymakers on how to reduce harms from the use of high potency cannabis products. It may indicate the need for caps on the potency of cannabis products or higher taxes on more potent cannabis products to discourage their heavy use (26). It is also needed to inform the labeling of THC doses in legal cannabis products that may include standardized THC doses analogous to standard units of alcohol (27). 


\section{AUTHOR CONTRIBUTIONS}

WH and JL: design and conception. JL, DS, and DD: acquisition and analysis of data. JL and DD: first draft. All authors: interpretation of data, subsequent drafts, revision for important intellectual content, final approval, and agreement to be accountable for the work.

\section{FUNDING}

JL was supported by the University of Queensland Development Fellowship (1833885).

\section{REFERENCES}

1. Hall W, Stjepanović D, Caulkins J, Lynskey M, Leung J, Campbell G, et al. Public health implications of legalising the production and sale of cannabis for medicinal and recreational use. Lancet. (2019) 394:158090. doi: 10.1016/S0140-6736(19)31789-1

2. Van Der Pol P, Liebregts N, Brunt T, Van Amsterdam J, De Graaf R, Korf DJ, et al. Cross-sectional and prospective relation of cannabis potency, dosing and smoking behaviour with cannabis dependence: an ecological study. Addiction. (2014) 109:1101-9. doi: 10.1111/add.12508

3. Freeman TP, Van Der Pol P, Kuijpers W, Wisselink J, Das RK, Rigter $\mathrm{S}$, et al. Changes in cannabis potency and first-time admissions to drug treatment: a 16-year study in the Netherlands. Psychol Med. (2018) 48:234652. doi: $10.1017 / \mathrm{S} 0033291717003877$

4. Freeman TP, Morgan CJ, Hindocha C, Schafer G, Das RK, Curran HV. Just say "know:" how do cannabinoid concentrations influence users' estimates of cannabis potency and the amount they roll in joints? Addiction. (2014) 109:1686-94. doi: 10.1111/add.12634

5. Cappell H, Kuchar E, Webster CD. Some correlates of marihuana selfadministration in man: a study of titration of intake as a function of drug potency. Psychopharmacologia. (1973) 29:177-84. doi: 10.1007/BF004 14031

6. Cappell H, Pliner P. Regulation of the self administration of marihuana by psychological and pharmacological variables. Psychopharmacologia. (1974) 40:65-76. doi: 10.1007/BF00429448

7. Korf DJ, Benschop A, Wouters M. Differential responses to cannabis potency: a typology of users based on self-reported consumption behaviour. Int J Drug Policy. (2007) 18:168-76. doi: 10.1016/j.drugpo.2006. 08.002

8. Reinarman C. Cannabis policies and user practices: market separation, price, potency, and accessibility in Amsterdam and San Francisco. Int J Drug Policy. (2009) 20:28-37. doi: 10.1016/j.drugpo.2007.11.003

9. Hartman RL, Anizan S, Jang M, Brown TL, Yun K, Gorelick DA, et al. Cannabinoid disposition in oral fluid after controlled vaporizer administration with and without alcohol. Forensic Toxicol. (2015) 33:26078. doi: 10.1007/s11419-015-0269-6

10. Hartman RL, Brown TL, Milavetz G, Spurgin A, Gorelick DA, Gaffney G, et al. Controlled cannabis vaporizer administration: blood and plasma cannabinoids with and without alcohol. Clin Chem. (2015) 61:85069. doi: 10.1373/clinchem.2015.238287

11. Bidwell LC, Ellingson JM, Karoly HC, Yorkwilliams SL, Hitchcock LN, Tracy BL, et al. Association of naturalistic administration of cannabis flower and concentrates with intoxication and impairment. JAMA Psychiatry. (2020) 77:787-96. doi: 10.1001/jamapsychiatry.2020.0927

12. Domino EF, Rennick P, Pearl JH. Dose effect relations of marijuana smoking on various physiological parameters in experienced male users. Observations on limits of self titration of intake. Clin Pharmacol Therapeut. (1974) 15:51420. doi: $10.1002 /$ cpt1974155514

13. Perez-Reyes M, Di Guiseppi S, Davis KH, Schindler VH, Cook CE. Comparison of effects of marihuana cigarettes to three different

\section{ACKNOWLEDGMENTS}

We would like to acknowledge the assistance of librarian Miranda Newell, The University of Queensland, for her assistance with the search.

\section{SUPPLEMENTARY MATERIAL}

The Supplementary Material for this article can be found online at: https://www.frontiersin.org/articles/10.3389/fpsyt. 2021.630602/full\#supplementary-material

potencies. Clin Pharmacol Ther. (1982) 31:617-24. doi: 10.1038/clpt. 1982.86

14. Herning R, Hooker W, Jones R. Tetrahydrocannabinol content and differences in marijuana smoking behavior. Psychopharmacology. (1986) 90:160-2. doi: 10.1007/BF00181232

15. Chait LD. Delta-9-tetrahydrocannabinol content and human marijuana self-administration. Psychopharmacology. (1989) 98:51-5. doi: 10.1007/BF00442005

16. Heishman SJ, Stitzer ML, Yingling JE. Effects of tetrahydrocannabinol content on marijuana smoking behavior, subjective reports, and performance. Pharmacol Biochem Behav. (1989) 34:1739. doi: 10.1016/0091-3057(89)90369-9

17. Matthias P, Tashkin DP, Marques-Magallanes JA, Wilkins JN, Simmons MS Effects of varying marijuana potency on deposition of tar and delta9-THC in the lung during smoking. Pharmacol Biochem Behav. (1997) 58:114550. doi: 10.1016/S0091-3057(97)00328-6

18. Freeman TP, Winstock AR. Examining the profile of high-potency cannabis and its association with severity of cannabis dependence. Psychol Med. (2015) 45:3181-9. doi: 10.1017/S0033291715001178

19. Chan GCK, Hall W, Freeman TP, Ferris J, Kelly AB, Winstock A User characteristics and effect profile of Butane Hash Oil: an extremely high-potency cannabis concentrate. Drug Alcohol Depend. (2017) 178:328. doi: 10.1016/j.drugalcdep.2017.04.014

20. Hines LA, Freeman TP, Gage SH, Zammit S, Hickman M, Cannon $\mathrm{M}$, et al. Association of high-potency cannabis use with mental health and substance use in adolescence. JAMA Psychiatry. (2020) 77:104451. doi: 10.1001/jamapsychiatry.2020.1035

21. Leung J, Chiu V, Chan GCK, Stjepanović D, Hall WD. What have been the public health impacts of cannabis legalisation in the USA? A review of evidence on adverse and beneficial effects. Curr Addict Rep. (2019) 6:41828. doi: 10.1007/s40429-019-00291-x

22. Chan GCK, Hall W. Estimation of the proportion of population cannabis consumption in Australia that is accounted for by daily users using Monte Carlo Simulation. Addiction. (2020) 115:1182-6. doi: 10.1111/add.14909

23. Newmeyer MN, Swortwood MJ, Barnes AJ, Abulseoud OA, Scheidweiler $\mathrm{KB}$, Huestis MA. Free and glucuronide whole blood cannabinoids' pharmacokinetics after controlled smoked, vaporized, and oral cannabis administration in frequent and occasional cannabis users: identification of recent cannabis intake. Clin Chem. (2016) 62:1579-92. doi: 10.1373/clinchem.2016.263475

24. Cone EJ, Huestis MA. Relating blood concentrations of tetrahydrocannabinol and metabolites to pharmacologic effects and time of marijuana usage. Ther Drug Monit. (1993) 15:527-32. doi: 10.1097/00007691-199312000-00013

25. Lim CCW, Leung JKY, Connor JP, Hall WD, Gartner C, Cheng $\mathrm{BHC}$, et al. Availability of substances for use in personal vaporisers on three online cryptomarkets. Drug Alcohol Dependence. (2020) 217:108254. doi: 10.1016/j.drugalcdep.2020.108254

26. Shover CL, Humphreys K. Six policy lessons relevant to cannabis legalization. Am J Drug Alcohol Abuse. (2019) 45:698706. doi: 10.1080/00952990.2019.1569669 
27. Freeman TP, Lorenzetti V. "Standard THC units:" a proposal to standardize dose across all cannabis products and methods of administration. Addiction. (2020) 115:1207-16. doi: 10.1111/add.14842

Conflict of Interest: The authors declare that the research was conducted in the absence of any commercial or financial relationships that could be construed as a potential conflict of interest.
Copyright $\odot 2021$ Leung, Stjepanović, Dawson and Hall. This is an open-access article distributed under the terms of the Creative Commons Attribution License (CC $B Y)$. The use, distribution or reproduction in other forums is permitted, provided the original author(s) and the copyright owner(s) are credited and that the original publication in this journal is cited, in accordance with accepted academic practice. No use, distribution or reproduction is permitted which does not comply with these terms. 